International Journal of Engineering \& Technology, 7 (4.19) (2018) 763-771
International Journal of Engineering \& Technology
SPC
Website: www.sciencepubco.com/index.php/IJET
Research paper

\title{
Experimental and Numerical Investigation for R/C Portal Frames Tested Under Uniform Load
}

\author{
Jaafar Dheyaa Jaafar Witwit ${ }^{1 *}$, Nameer Abed Al-Ameer Alwash ${ }^{2}$ \\ ${ }^{1}$ M.Sc. Degree in Civil Engineering Department, University of Babylon \\ ${ }^{2}$ Professor in Civil Engineering Department, University of Babylon \\ *Corresponding Author Email: Eng_JDJW@outlook.com
}

\begin{abstract}
This paper presents an experimental and numerical investigations for three reinforced self-compacting concrete portal frames tested under uniform load. Control frame was tested without any types of strengthening, while second frame was strengthened with CFRP-sheet with dimensions $(75 * 1000) \mathrm{mm}$ at the bottom of beam and with dimensions ( $75 * 700) \mathrm{mm}$ at both joints, $(350 \mathrm{~mm})$ extending to the upper surface of the beam and $(350 \mathrm{~mm})$ on the outer face of the column. The last frame was cast in two pours tested without strengthening. The experimental tests showed that strengthened frame had stiffness more than control frame and its ultimate load was more than control frame by $(19.45 \%)$, while frame with two pours has an ultimate load less than a control frame with (11.26 \%), however stiffness seem approximately to the control frame. Deflection for strengthened frame was less than control frame by (4.76\%), on the other hand frame with two pours deflection was more than control frame by $(4.55 \%)$. A numerical finite element program ultimate load was more than experimental by about $(4.28 \%)$.
\end{abstract}

Keywords: Reinforced Concrete Portal Frames, Self-Compacting concrete, Uniformly Distributed Load, CFRP Sheets.

\section{Introduction}

Al-Janabi, M. A. Q. and Alwash, N. A.(2003), presented a general analytical method of the inelastic behavior of reinforced concrete (plane or space) frames. Also, one model of a reinforced concrete space frame was cast and tested experimentally up to failure.

Zou, X.K. and Chan, C. M. (2004), studied lateral drift of structures by a program based on the performance - based design concept, illustrative of the program was checked by a ten-story two bays reinforced concrete plane frame, which was under gravity load, live load and lateral load.

Mar1'a E. Maranteand et.al.(2005), designed in 2005, a portal damage program to simulate the behavior of portal frame under seismic load and overload. Cracking in reinforced concrete assumed to follow as Griffith criterion. A finite element results compared with experimental results to check the program. The first example was with a reinforced concrete column in a cantilever subjected to complex loads, for this example, although hthe best results, but the results were underestimated because of the classic reinforced concrete theory. The second experimental example was a two-story reinforced concrete frame subjected to axial load with lateral displacement. The last example was a 10story RC frame designed according to the current Venezuelan code. This frame subjected to many spectrums of earthquake and measured the damage in the frame. This example represents a real test to a portal damage; however, the numerical results were good. Guerra, A. and Kiousis, P. D.(2006), studied in 2006, formulation to achieve optimal design for reinforced concrete structures, multibay and multi-story. Optimal size, optimal stiffness, materials and labor costs considered in a nonlinear programming algorithm by using MATLAB (Mathworks, Inc.) to satisfy ACI 2005 code requirements.
CengizDundar and IlkerFatih Kara(2007), developed a three dimensional analysis program for cracked beam and column elements. Shear stiffness, reduce considered in the model when the cracks initiate. This method is more direct than finite element method. Numerical results were verified by experimental results and give a good response. The first example was a reinforced concrete frame with two-story and the discrepancies between experimental and numerical results were $11 \%$ only. Second example was also two-story frame and the results were agreed after applying lateral load up to $78 \%$ of ultimate load. Finally, the last example was a four-story building. A uniform and lateral load were

applied gradually on the frames. The lateral displacement between the first story and the second one was increased when the lateral load increased. Two cases of cracking beams and columns and not cracking were considered. In this study shear stiffness reduction in reinforced concrete wall was not investigated, so inthe future, it may be studied to develop this method or by integrating with finite element method.

Al-Nasrawi, J.T.A. (2008), carried out in 2008, experimental investigation for five reinforced concrete space frames under cyclic load repaired and strengthened with CFRP - sheet. Also, analytical study was presented.

The present work Investigates experimental and numerical behavior of reinforced concrete portal frames strengthening by CFRP-sheet and tested under uniform load, also for frame cast in two pours (i.e. Cast columns separately from beam).

VikasGohel and et.al (2013), developed a new displacement based Applied Element Method (AEM). In this method structure divided into many elements. These elements are connected together by three springs one for normal and two for shear. This method is able to analyze structure in static linear stage and in nonlinear stage. The advantage of this method is to simulate the loading 
steps from zero to collapse. With Finite Element Method (FEM) it is difficult to represent cracks, but with this method it is very easy. Also, other differences between (FEM) and (AEM) were listed on paper. Comparison between FEM and (AEM) gives good results, so we can use (AEM) to analyze structures.

Behrouz Behnam, and et. al. (2014), studied a high-risk load by applying post-earthquake fire (PEF) on buildings. Two story RC frame was designed according to ACI 318-08. Test results showed that the structure is very weak to resist post-earthquake fire, so it is necessary to take this fact in structures design. Using CFRP warp resulted to increase structural load capacity because of relocating plastic hinges away from the column faces towards the beams so resistance to post-earthquake fire (PEF) increase Experimental results showed that beam resistance to fire was 2hours while column resistance was 3 hours, Also frame resistance was near to beam resistance. Using CFRP gives additional one hour to fire resistance for the frame. Numerical investigation was done by using (FEMA356) program, Also it was checked by using ABAQUS.

MihaJukic' and et. al (2014), present a multi- layer beam finite element formulation to analyze reinforced concrete frame, this formulation was based on Timoshenko beam model. Convergence study for finite element to frame was done. The formulation was assessed by many experimental results, which is symmetric frame with two hinged-support, portal frame with an initial imperfection and Two-story reinforced concrete frame. A comparison between numerical and experimental results gives a good response.

\subsection{Self - Compacting Concrete (SCC)}

Self-compacting concrete(SCC) can be defined as the concrete that has the ability to compact itself without using vibration and it flows without segregation by its own weight. It also has the ability to fill the formwork even there is a dense reinforcement. Selfcompacting hard concrete is dense, homogenous and has a strength more than ordinary concrete(Al-Mishhadani 2009),(EFNARC 2005).

\subsection{Joint Failure Types}

There are many types of failure in frame, which is(Al-Shimmari 2006):

a- Hinging of the beams at the connection.

b- Hinging of the column.

c- Loss of the concrete cover over the reinforcement in the beamcolumn core.

d- Failure of reinforcement anchorage at joint.

e- The consequences of failure of the connection in shear.

\section{Used Materials in Fabrication the Specimens}

The materials were used in designing and casting of reinforced concrete portal frames were commercially available in Iraq. These materials include cement, fine aggregates, coarse aggregates, superplasticizer and steel reinforcing bar, Also, CFRP sheets and epoxy resin were used for strengthening frames. The properties and specifications of these materials were as follows:

\subsection{Cement}

Ordinary Portland cement manufactured by (Tasluja - Bazian) produced in Iraq was used in this study, which satisfied to the (Iraq Specification No.5 1984).

\subsection{Fine Aggregate (sand)}

Natural sand obtained from (Al-Akhaidur) region was used in concrete mixes in this study. The sand was washed, cleaned with water and dried before use. The grading test results conform to the (Iraq Specification No. 45 1984).

\subsection{Coarse Aggregate (gravel)}

Natural rounded gravel of maximum size $10 \mathrm{~mm}$ obtained from (Al-Nebai region) was used with grading satisfied to the(Iraq Specification No. 45 1984).

\subsection{Superplasticizer}

The new generation of Super plasticizer Sika ViscoCrete ${ }^{\circledR}-5930$ was used to reduce water content and to obtain high workability for fresh concrete with a nominal dosage of $5.76(1 / \mathrm{m} 3)$. Reducing water/ cement (W/C) ratio leads to increase the strength of concrete. On the other hand, use of super plasticizer increases workability.

\subsection{Steel Reinforcement}

Deformed steel bars $(\Phi 8 \mathrm{~mm}$ and $12 \mathrm{~mm}$ ) in diameter were used as reinforcement to tested frames which made at Ukraine. Three specimens of each bar are tested under tension in Laboratory of Material related to the Material Engineering Faculty at University of Babylon. The results of testing steel reinforcement are listed in Table (1).

Table 1: Properties of steel reinforcement

\begin{tabular}{|c|c|c|c|c|c|c|}
\hline $\begin{array}{c}\text { Nominal } \\
\text { dia. } \\
(\mathrm{mm})\end{array}$ & $\begin{array}{c}\text { Actual } \\
\text { dia. } \\
(\mathrm{mm})\end{array}$ & $\begin{array}{c}\text { As } \\
\left(\mathrm{mm}^{2}\right)\end{array}$ & $\begin{array}{c}\text { fy } \\
(\mathrm{MPa})\end{array}$ & $\begin{array}{c}\text { fu } \\
(\mathrm{MPa})\end{array}$ & $\begin{array}{c}\text { Modulus } \\
\text { of } \\
\text { elasticity }\end{array}$ & Elongation \\
\hline 8 & 7.87 & 48.64 & 467 & 569 & 200000 & 11.4 \\
\hline 12 & 11.94 & 111.97 & 655 & 714 & 200000 & 13.9 \\
\hline
\end{tabular}

\subsection{CFRP Properties}

The type of CFRP sheet was used in this study is (Sika Warp sheet ${ }^{\circledR}$ Hex-230C). When tension load is applied on CFRP fiber, they do not have any plastic (yielding) behavior before rupture. The tensile behavior is characterized by a linear elastic stressstrain relationship up for failure, which is sudden and can be catastrophic. The properties of the CFRP - sheet listed in Table (2)(Sika 2009).

Table 2: Properties of carbon fiber fabric laminate(Sika, 2009)

\begin{tabular}{|c|c|c|c|}
\hline $\begin{array}{c}\text { Tensile strength } \\
(\mathrm{MPa})\end{array}$ & $\begin{array}{c}\text { Tensile E-modulus } \\
(\mathrm{MPa})\end{array}$ & $\begin{array}{c}\text { Thickness } \\
(\mathrm{mm})\end{array}$ & $\begin{array}{c}\text { Elongation } \\
(\%)\end{array}$ \\
\hline 4300 & 234000 & 0.131 & 1.8 \\
\hline
\end{tabular}

\subsection{Epoxy Resin}

Epoxy resin of type Sikadur-330, combined from two parts (Resin part A + Hardener part B), was used as a glue to CFRP sheet. The manufacturer's specifications of Sikadur-330 were listed in Error! Reference source not found.) (Sika 2005).

Table 3: Properties of (Sikadur-330)

\begin{tabular}{|} 
Table 3: Properties of (Sikadur-330) \\
\begin{tabular}{|c|c|}
\hline Properties & Sikadur®)-330 \\
\hline Tensile strengths, $(\mathrm{MPa})$ & $30 \mathrm{MPa}$ \\
\hline Modulus of elasticity, $(\mathrm{MPa})$ & 4500 \\
\hline Elongation at break, $(\%)$ & $0.9 \%$ \\
\hline Open time, $($ minute $)$ & $30\left(\right.$ at $\left.+35^{\circ} \mathrm{C}\right)$ \\
\hline Full cure, $($ days $)$ & $7\left(\mathrm{at}+35^{\circ} \mathrm{C}\right)$ \\
\hline Mixing ratio & Part A: part $\mathrm{B}=4: 1$ by weight \\
\hline
\end{tabular}
\end{tabular}

\subsection{Frame Specimens Reinforcements}

Three frame specimens were cast. The frames were designed according to (ACI-318, 2011). The reinforcement was designed to prevent shear failure in the frame. And the flexural reinforcement 
was designed with $(\rho=0.00881)$ as shown in Fig $)$.

\section{Specimens Description}

Three specimens were tested under monotonic uniform load up to failure, one was the control frame other one was cast in two pours (i.e. Cast columns first separately from a beam) and last one was strengthened by CFRP-sheet. Notations for these frames as below:

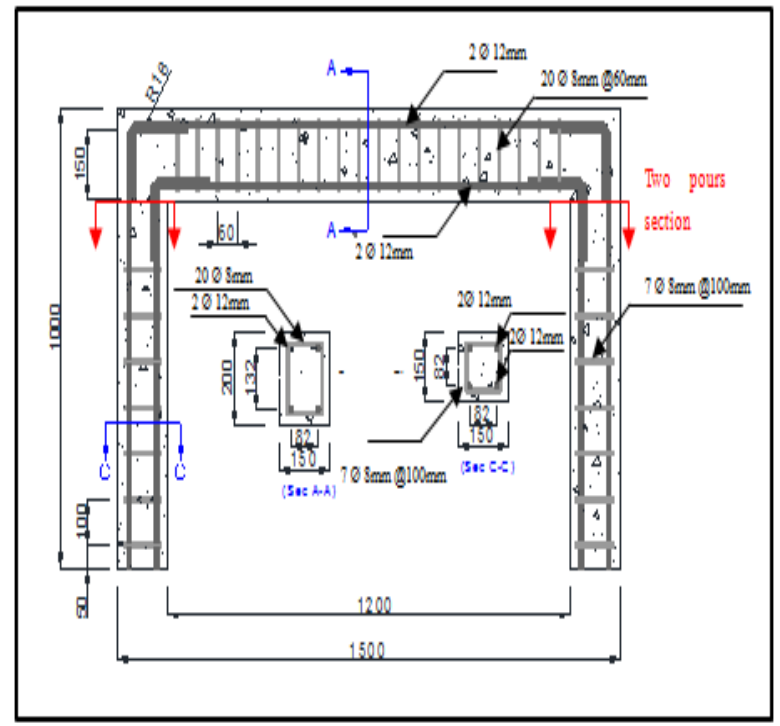

Fig. 1: Reinforcement details of all frames showing two pours sections

1- Fu-Co: Control frame tested under uniform load.

2- Fu-2P: Frame cast in two pours tested under uniform load.

3- Fu-S: Strengthened frame with CFRP-sheet tested under uniform load.

The types of strengthening shown in Fig) below.

\subsection{Uniform Load System}

It consisted of multi simply-supported rigid steel beams, every one of them supported with two rods as simply supported beam and carried loads from the press to the frame uniformly on steel bearing plates to prevent local crushing in concrete(Shawkat 2008). Fig) shows uniform load system schematically.

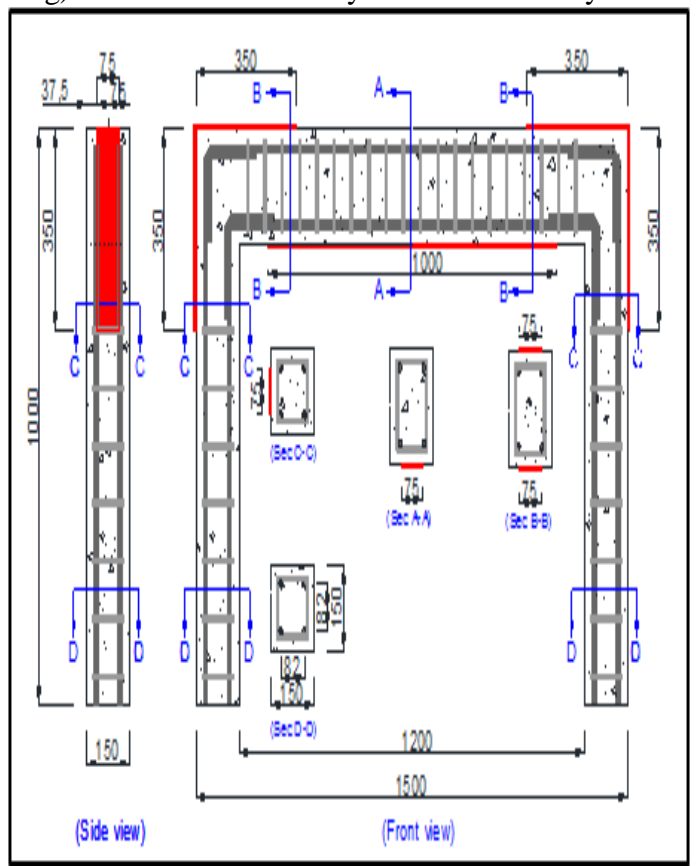

Fig. 2: Strengthening and reinforcement for frames (Fu-S)

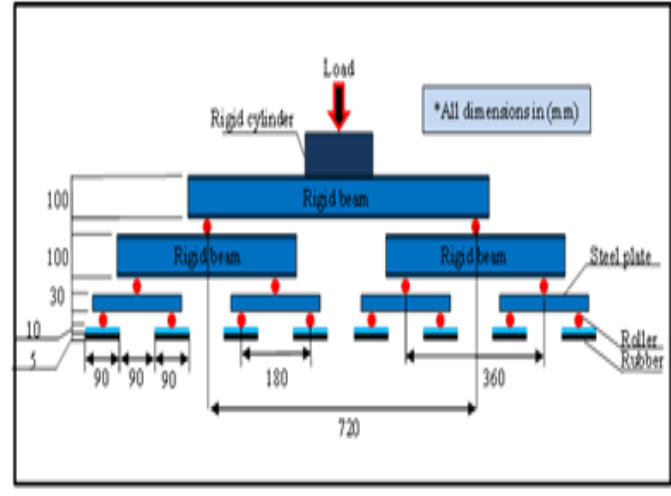

Fig. 3: Uniform load system

\subsection{Support cups}

The two columns of the frame supported into two cups of hardened steel and rounded by four side thin plate to prevent crushing of concrete, and there were two thin plates under the columns for the same reason. Fig)shows the dimensions of the column cups.

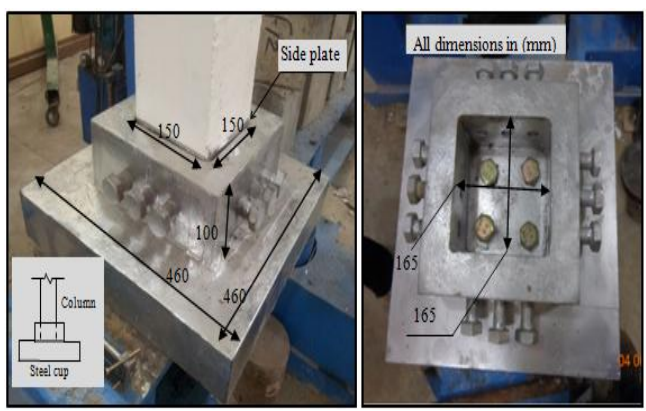

Fig. 4: Columns support dimensions

\subsection{Test setup}

The load applied on specimen monotonically step by step until failure occurred. Load steps were $20 \mathrm{kN}$ for each step with increasing rate was $0.5 \mathrm{kN} / \mathrm{sec}$. In each step, dial gages values, first crack width values and demec points values were measured.

\section{Mix Design and Proportion}

Many trial mixes have been done before choose the achieved mix for this present work. The trial mixes were tested at the ages of (28 day).The achieved mix which gives the best concrete properties. The self-compacting concrete mix was designed according to EFNARC 2005 specification to achieve average cylinder compressive strength of (39.4 MPa) at 28 days.

Table 4) shows the details of mixture.

\begin{tabular}{|c|c|} 
Table 4: Concrete mix detail \\
\hline Materials & Amount \\
\hline Cement $(\mathrm{kg} / \mathrm{m} 3)$ & 475 \\
\hline Fine aggregate $(\mathrm{kg} / \mathrm{m} 3)$ & 775 \\
\hline Course aggregate $(\mathrm{kg} / \mathrm{m} 3)$ & 800 \\
\hline Limestone Powder $(\mathrm{kg} / \mathrm{m} 3)$ & 125 \\
\hline Water $(1 / \mathrm{m} 3)$ & 157 \\
\hline SPSikaViscoCrete ${ }^{\circledR}-5930(1 / \mathrm{m} 3)$ & 5.76 \\
\hline $\begin{array}{c}\text { Water/Powder, Powder }=\text { Cement }+ \text { Limestone } \\
(\mathrm{W} / \mathrm{P})\end{array}$ & 0.262 \\
\hline W/C & 0.33 \\
\hline
\end{tabular}

A fresh concrete properties for this mix is shown in

Table 5) below and their limitations are according to EFNARC specifications. 


\begin{tabular}{|c|c|c|c|c|}
\hline \multicolumn{1}{|c}{ Table 5: Fresh concrete properties } \\
\hline Test Methods & Properties & Class & Values & $\begin{array}{c}\text { Limits } \\
\text { according to } \\
\text { EFNARC }\end{array}$ \\
\hline $\begin{array}{c}\text { Slump-flow } \\
(\mathrm{mm})\end{array}$ & $\begin{array}{c}\text { flowability/filling } \\
\text { ability }\end{array}$ & $\mathrm{SF} 2$ & 673 & $\begin{array}{c}640-800 \\
\mathrm{~mm} 6\end{array}$ \\
\hline $\mathrm{T}_{500} \mathrm{~mm}(\mathrm{sec})$ & Filling ability & $\mathrm{SF} 2$ & 5 & $2-5 \mathrm{sec}$ \\
\hline V-funnel (sec) & $\begin{array}{c}\text { Viscosity/ } \\
\text { flowability }\end{array}$ & $\mathrm{VF} 2$ & 20 & $7-27 \mathrm{sec}$ \\
\hline $\begin{array}{c}\text { V-funnel at T5 } \\
\text { minutes (sec) }\end{array}$ & $\begin{array}{c}\text { Segregation } \\
\text { resistance }\end{array}$ & $\mathrm{VF} 2$ & 25 & $+3 \mathrm{sec}$ \\
\hline L-box & Passing ability & $\mathrm{PA} 2$ & 0.895 & $\begin{array}{c}\mathrm{H}_{2} / \mathrm{H}_{1}=0,8- \\
1,0\end{array}$ \\
\hline
\end{tabular}

\section{Concrete Casting and Curing}

Before mixing materials, aggregates were weighted and stored in closed containers in the laboratory. The internal surfaces of molds, cubes, cylinders and prisms were well cleaned and oiled to avoid adhesion with concrete after hardening.

The procedure to mix SCC is stated in the following steps:

1 - The fine aggregates were added to the mixer with $1 / 3$ quantity of water and mixed for one minute.

2- The powder (cement + Lime stone) was added with another $1 / 3$ quantity of water after that the mixture mixed for one minute.

3- The coarse aggregate was added with the last $1 / 3$ quantity of water and $1 / 3$ of superplasticizer, and mixing lasts for 1.5 minutes.

4- Rest for 0.5 minutes.

5- Finally, adding $2 / 3$ of SP and mixing for 1.5 minutes.

After one day of the casting all frame specimens, curing by water to the frames, cubes, cylinders and prisms were done after covered by burlap sacks to keep them wet. Fig) shows curing process to the tested frames.

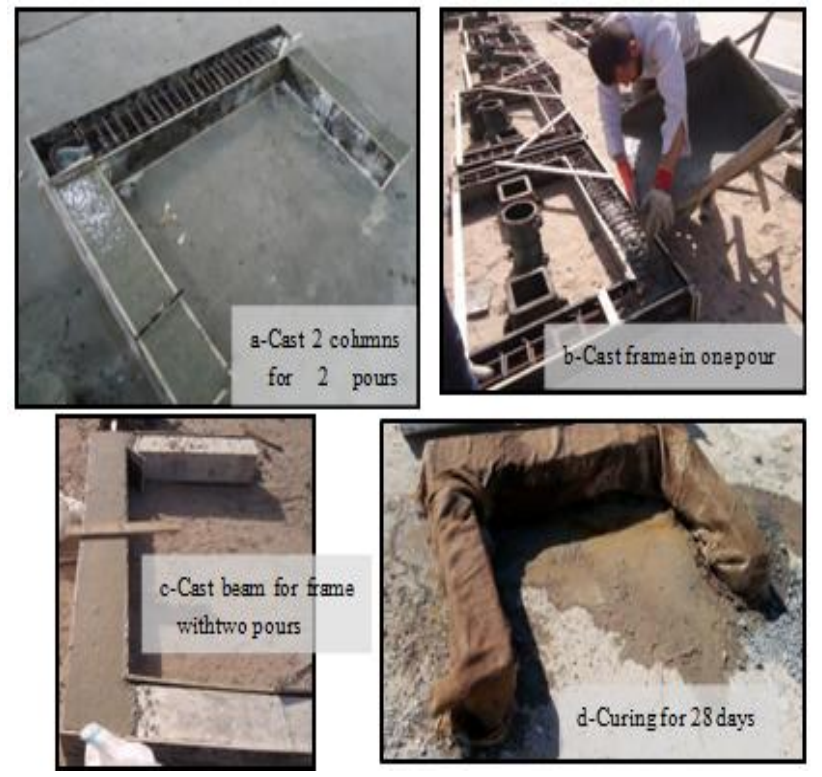

Fig. 5: Concrete casting and curing steps

\section{CFRP Installation on Frame}

The applying procedure for CFRP - sheet was according to the recommendation of (ACI Committee 440.2R-08 2008), as shown: 1- Preparation of concrete surface before applying CFRP the surface of concrete must be grounded by using electric hand grinder after that washed with water to obtain a clean surface. That clean surface ensures good bond between CFRP and the concrete surface.

2- Marketing frames on the region that want to strength it Cutting CFRP-sheet in required length and concrete surface must be cleaned from any contaminations in preparation and washed by water.

3- Two types of epoxy (white and black) mixed together in the proportion (4:1) respectively till the color be homogenous.

4- Applying epoxy on frame and CFRP-sheet with thickness about $1.5 \mathrm{~mm}$.

5- After that, setting CFRP-sheet on frame surface in the coated region by epoxy and pressure

6- Applying by a rubber roller to seat the sheet by that cause epoxy forced out from both sides of the sheet.

7- Excess epoxy removed from the sides of a CFRP - sheet.

8- Finally, the frame is ready to test after curing for 7 days at laboratory temperature $35^{\circ} \mathrm{C}$.

These steps shown in Fig).
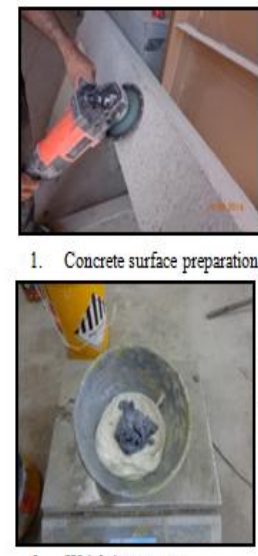

3. Weighting epoxy

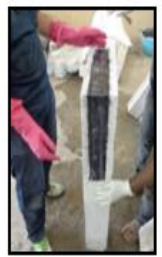

7. Applying CFRP on frames

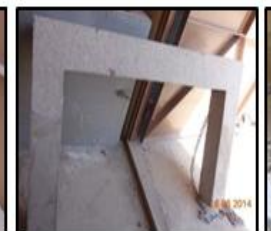

or frames by hand grinder
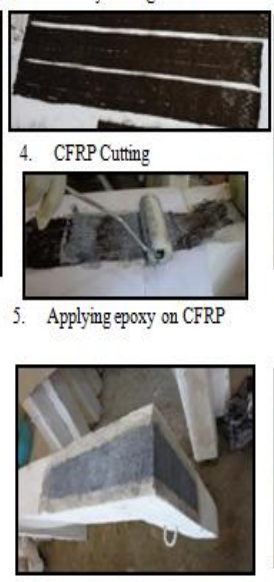

8. CFRP setting on frames

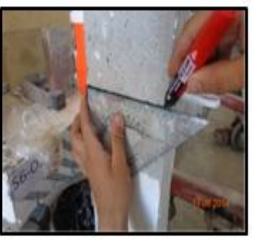

2. Frame marking

6. Applying epoxy on frame

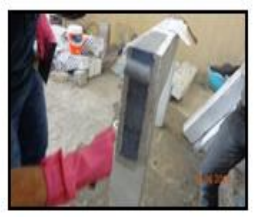

9. Curing for 7 days

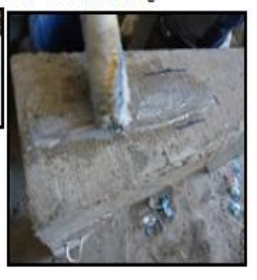

Fig. 6: CFRP- sheet setting on frame

\section{Mechanical Properties of Hardened Concrete}

\subsection{Compressive Strength Test}

The compressive strength test was carried out according to (BS 1881: Part 116. 1989) and (ASTM C39/C39M-05 2002).

The average of three cubes and cylinders was taken for each frame and listed in Table 6).

Table 6: Compressive strength for cube and cylinder test

\begin{tabular}{|c|c|}
\hline $\begin{array}{c}\text { Average of all specimens } \\
\text { attest time }(90 \text { days age })\end{array}$ & $\begin{array}{c}\text { Compressive Strength } \\
(\mathrm{MPa})\end{array}$ \\
\hline Cubes $(150 \times 150 \times 150) \mathrm{mm}$ & 49.4 \\
\hline Cylinder $(150 \times 300) \mathrm{mm}$ & 39.4 \\
\hline
\end{tabular}

\subsection{Splitting Tensile Strength Test}

The splitting tensile strength was determined according to the procedure outlined in (ASTM C496 2004)specification. The average of three cylinders was adopted at each test as listed in Table 7) below.

Table 7: Splitting tensile strength of concrete

\begin{tabular}{|c|c|}
\hline Cylinder $(100 \times 200) \mathrm{mm}$ & Splitting Tensile Strength $(\mathrm{MPa})$ \\
\hline $\begin{array}{c}\text { Average of all specimens at } \\
(90 \text { days age })\end{array}$ & 3.36 \\
\hline
\end{tabular}




\subsection{Flexural Strength Test (Modulus of Rupture)}

Concrete prisms of dimensions $(100 \times 100 \times 400) \mathrm{mm}$ were cast according to (ASTM C78 2002)procedure. Flexural strength expressed as the modulus of rupture was calculated using the results obtained from a simple beam using two-point.

The modulus of rupture of concrete was listed in Table 8).

Table 8: Modulus of rupture of concrete

\begin{tabular}{|c|c|}
\hline Prisms $(100 \times 100 \times 400) \mathrm{mm}$ & Flexural Tensile Strength $(\mathrm{MPa})$ \\
\hline Average of all specimens & 7.37 \\
\hline
\end{tabular}

\section{Experimental Results and Discussion}

\subsection{Cracking Patterns and Load - Crack Width Relationship}

The crack width at beam mid span and both joints were measured by using crack meter with accuracy was $(0.01) \mathrm{mm}$, as shown in Fig).The cracking patterns of each frame specimen will be discuss in the following:

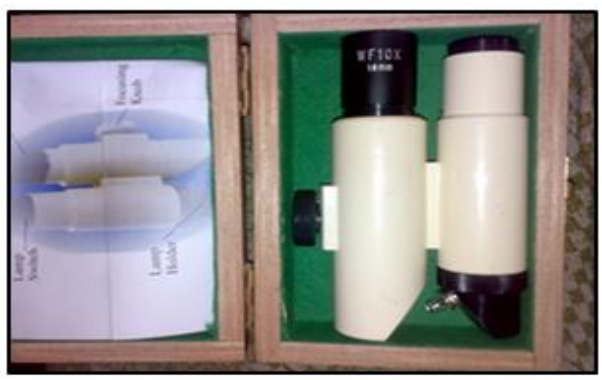

Fig. 7: Photograph for crack meter.

\section{* Frame (Fu-Co)}

This frame is a control frame which was cast in one pour and tested under uniform load without any type of strengthening.

This frame is gradually loaded until the cracks appeared; the first crack of this specimen appeared at one of the joints with load (33 $\mathrm{kN})$. Flexural cracks and joint cracks formed and widened as loading proceed as shown in Figure (7).The first crack width was $(0.075 \mathrm{~mm})$ at a joint. At service load, $(0.6$ ultimate load $=176$ $\mathrm{kN})$, the maximum crack width was $(0.21 \mathrm{~mm})$ at mid span Crushing at a compression zone in the inner face of the beamcolumn joints was $258 \mathrm{kN}$ caused by concrete failure at first joint Also, crushing occurred at mid span at load $(273 \mathrm{kN})$. After that, ultimate load was at load $(293 \mathrm{kN})$ caused by concrete failure at first join. Cracking pattern for frame Fu-Co is shown in Fig)and Load-crack width relationship shown in Fig).

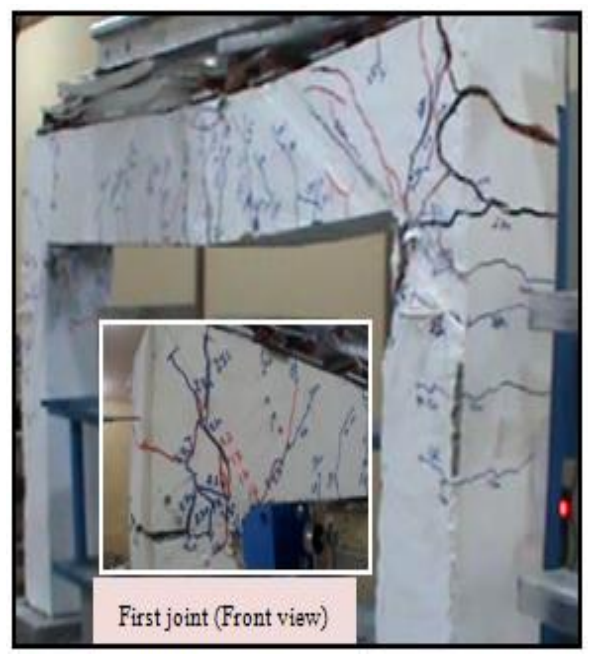

Fig. 8: Crack pattern for frame Fu-Co

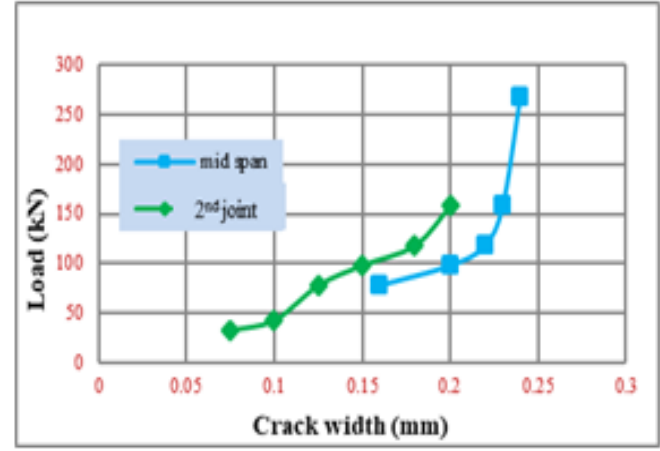

Fig. 9: Load-crack width relationship for frame ( $\mathrm{Fu}-\mathrm{Co})$

* Frame (Fu-S)

This specimen is the same as control frame, but with the strengthening of beam in bending and joints. CFRP sheet of length $(1.0 \mathrm{~m})$ and width $(75 \mathrm{~mm})$ for bending, while joints were strengthened with CFRP-sheet with length $(700 \mathrm{~mm})$ and width $(75 \mathrm{~mm})$; which is $(350 \mathrm{~mm})$ towards beam at negative moment region and $(350 \mathrm{~mm})$ continues to columns.

The first crack of this specimen appeared at load $(50 \mathrm{kN})$ almost at both joints see Fig). As the load was increased, the new cracks formed and widened in beam and joints. At service load, maximum crack width $(0.2 \mathrm{~mm})$ was at mid span. The failure occurred at a load $(350 \mathrm{kN})$ announced by CFRP sheet rupture at the mid span section, which is greater than the control beam by $(19.45 \%)$.

Load-crack width relationship of this frame is shown in Fig).

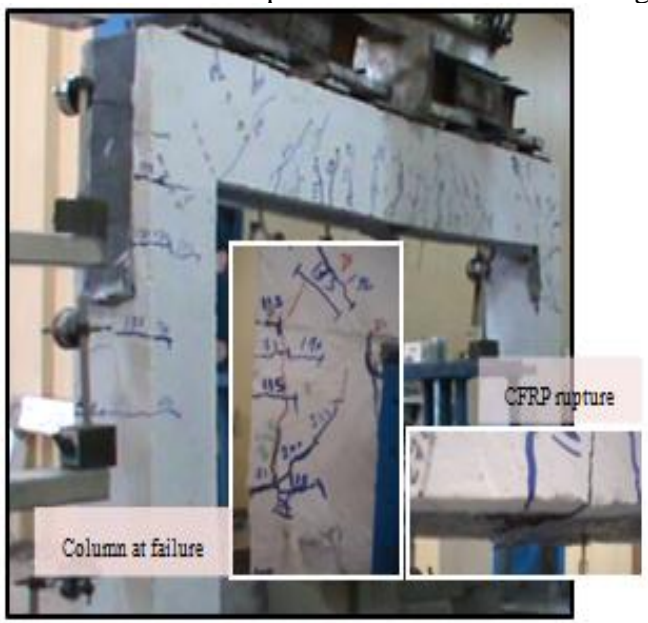

Fig. 10: Crack pattern for frame Fu-S

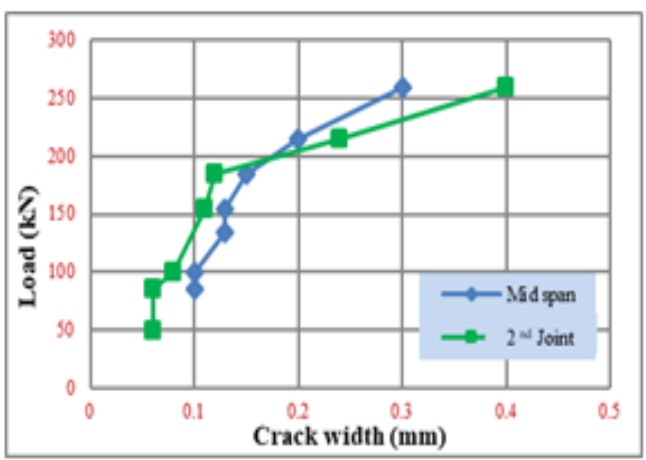

Fig. 11: Load-crack width relationship for frame (Fu-S)

\section{* Frame (Fu-2P)}

This specimen is similar to control frame; but this frame was cast in two pours (i.e. Cast columns separately from a beam), so that the beam column connection section was seemed to be rather weak and the failure happened rather early in this specimen. The second pour was done after 3 weeks without any preparing to 
contact surface.

The load was applied and increased gradually, first crack appeared at one of the joint with load $(25 \mathrm{kN})$, and widen gradually till service load, the crack width was $(0.22 \mathrm{~mm})$. The failure occurred at both joints at the weak section in beam column connection because of concrete failure at construction joints, at load (260 in) which is lower than the control frame with $(11.26 \%)$ because of the beam - column connection was separately cast. See Fig). Load-crack width relationship shown in Fig) below.

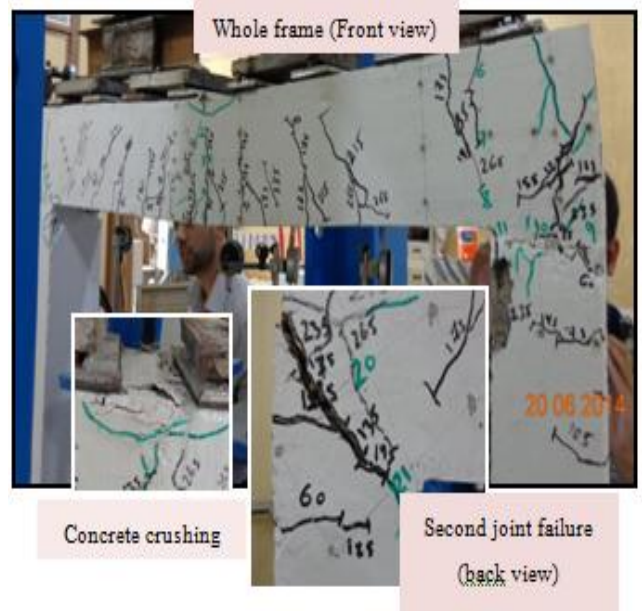

Fig. 12: Cracks pattern for frame (Fu-2P)

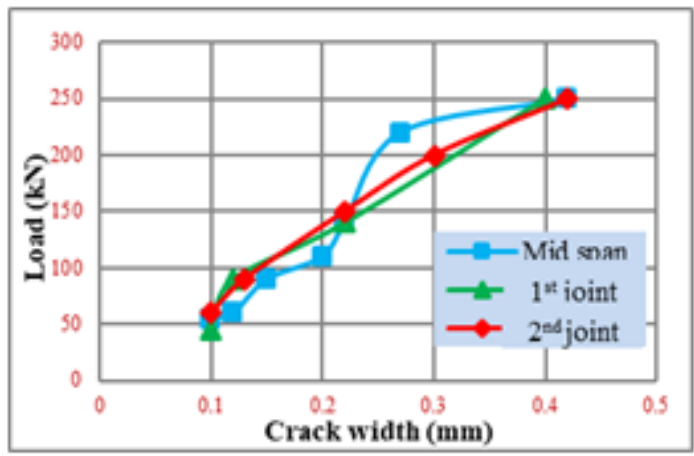

Fig. 13: Load-Crack width relationship for frame (Fu-2P)

\subsection{Load-Deflection Curves}

Five dial gages were installed below the beam to measure deflection at beam and four beside one of the columns to measure the lateral displacement of the column, so one can draw a deflected shape for frames. Dial gages used have $(50 \mathrm{~mm})$ travel distance and accuracy of $(0.01 \mathrm{~mm})$. Fig) shows dial gages distribution.

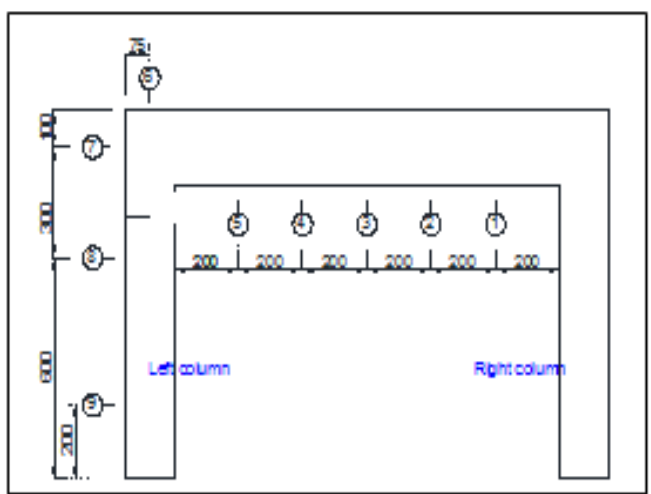

Fig. 14: Dial gages distribution on frame.

The load-mid span deflection curves for these frames shown in
Figure (14)below. From this figure noticed that the stiffness ofthe frame $(\mathrm{Fu}-2 \mathrm{P})$ was approximately similar to the control frame, but the ultimate load was less than control frame by (11.26\%) because of beam column separately cast, while stiffness for frame (Fu-S) is more than frame (Fu-Co) because of strengthening. Also, ultimate load was more than control frame by $(19.45 \%)$.

\subsection{Deflected Shape for Frames}

From Figure (15) to Figure (17) it is clear that the deflection of the frame $(\mathrm{Fu}-2 \mathrm{P})$ is larger than the control frame $(\mathrm{Fu}-\mathrm{Co})$ especially the lateral column drift. However, the strengthened frame (Fu-S) was stiffer than other frames especially at joints.

\subsection{Concrete Strain Distribution}

Many demec points installed on frame surface to measure the strain of concrete at several sections by extensometer with accuracy was $(0.002 \mathrm{~mm})$, as shown in Figure (18)

Concrete strain distribution for frames shown in Figure (19) to Figure (21). For frame (Fu-S) concrete strain distribution at mid span and joints were less than control frame because of strengthening, as shown in Figure (19). While concrete strain for frame with two pours $(\mathrm{Fu}-2 \mathrm{P})$ was more than the control frame $(\mathrm{Fu}-\mathrm{Co})$ at $\sec (\mathrm{C}-\mathrm{C})$ and $\sec (\mathrm{E}-\mathrm{E})$ because of beam and columns were cast separately, as shown in Figure (21).

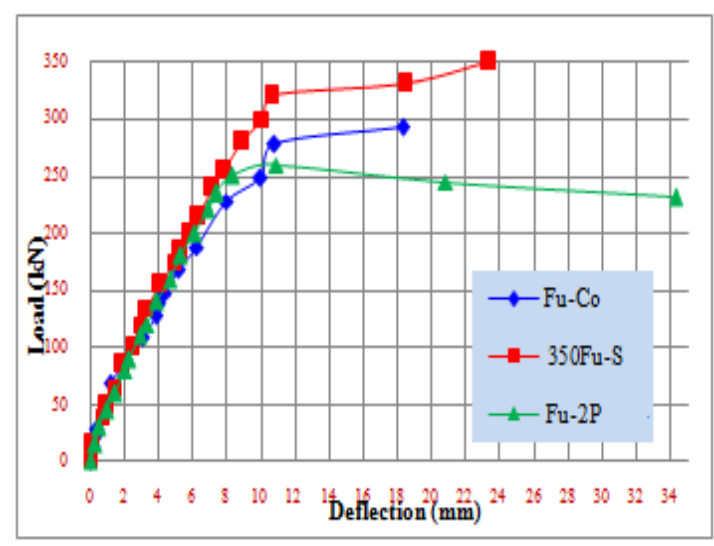

Fig. 14: Load deflection curves for testing frames

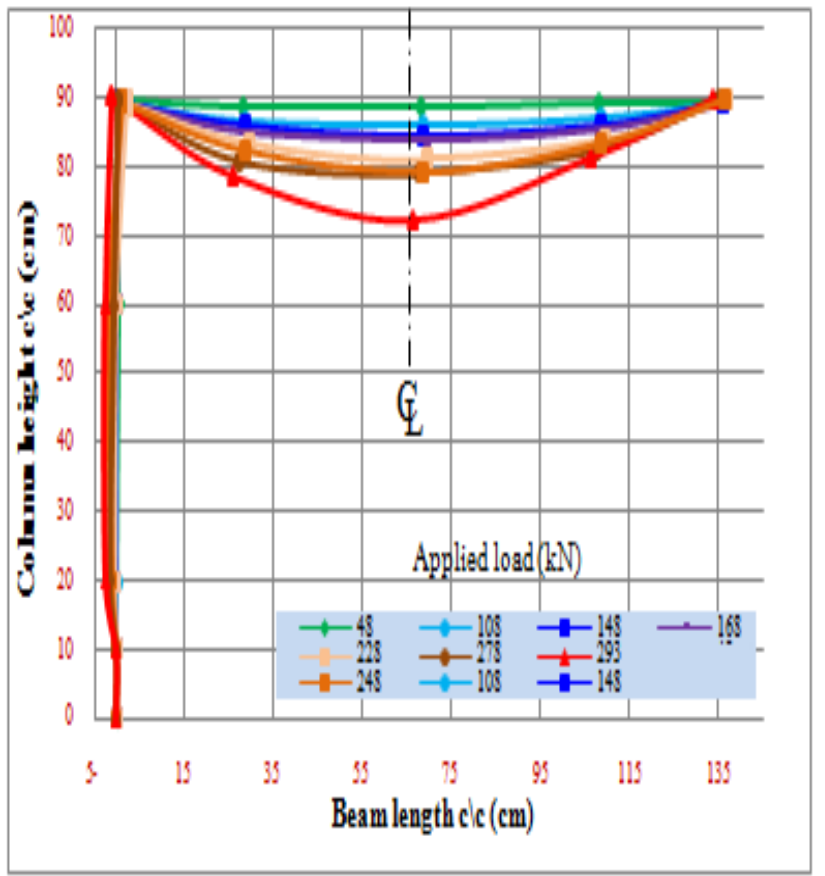

Fig. 15: Deflected shape for frame (Fu-Co) 


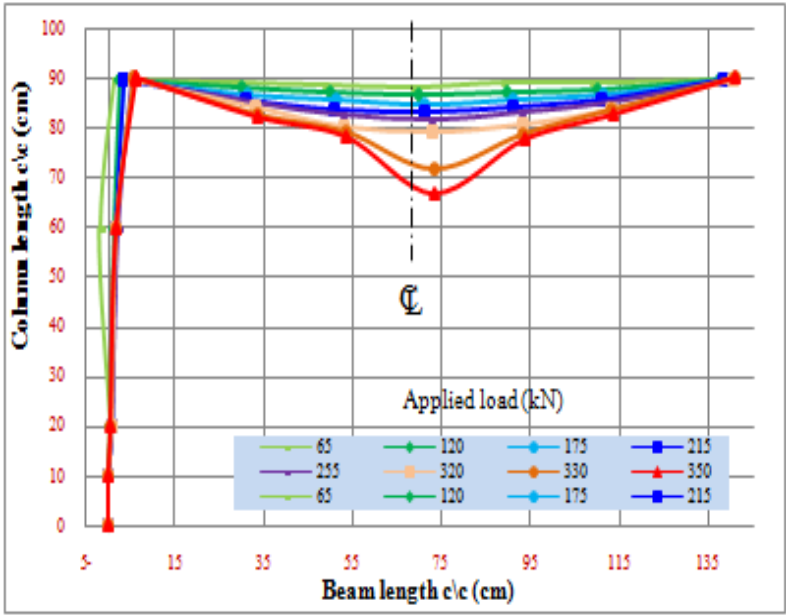

Fig. 16: Deflected shape of frame (Fu-S)

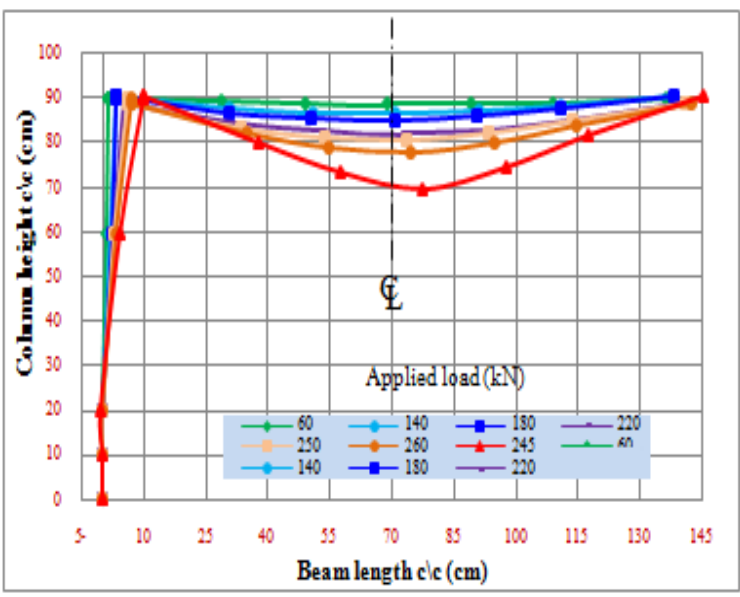

Fig. 17: Deflected shape of frame (Fu-2P)

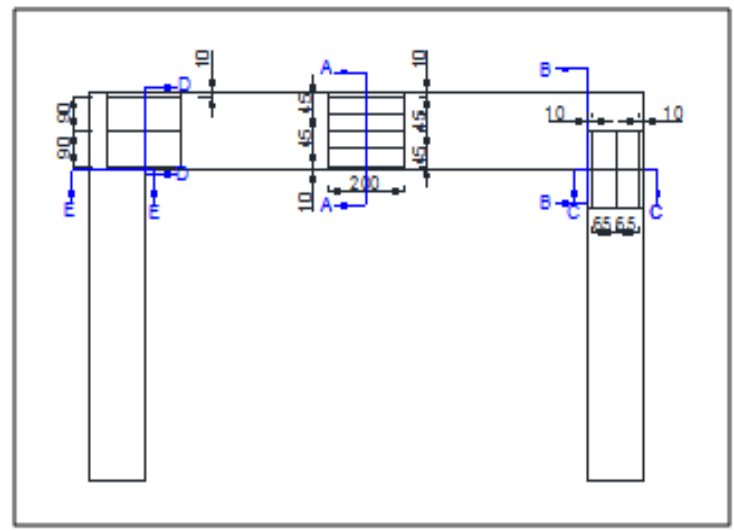

Fig. 18: Demec points distribution on frame surface
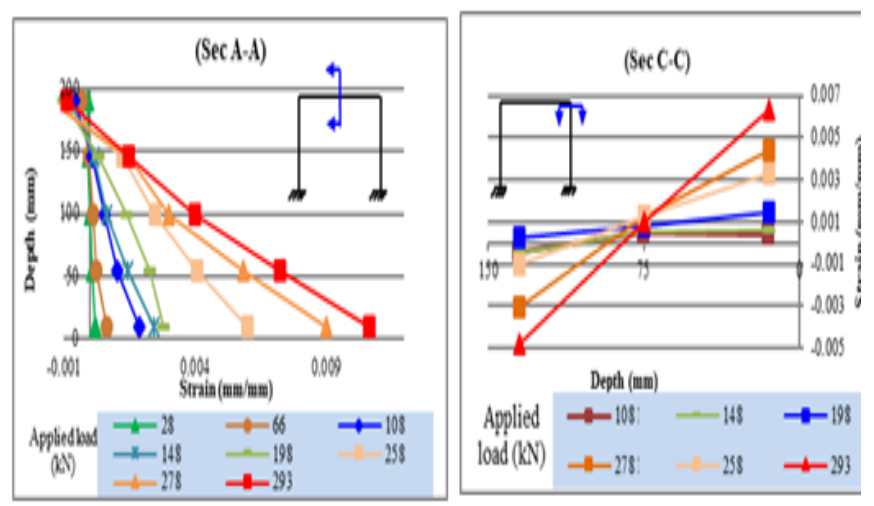

Fig. 19: Concrete strain distribution for frame ( $\mathrm{Fu}-\mathrm{Co})$
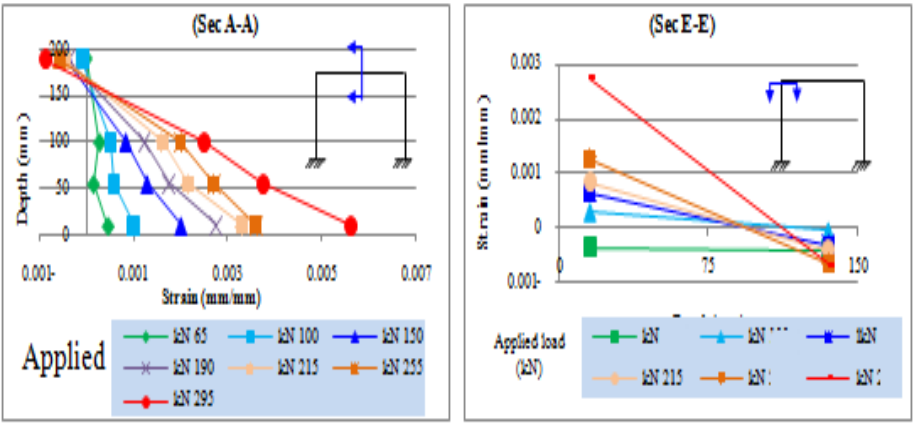

Fig. 20: Concrete strain distribution for frame (Fu-S)
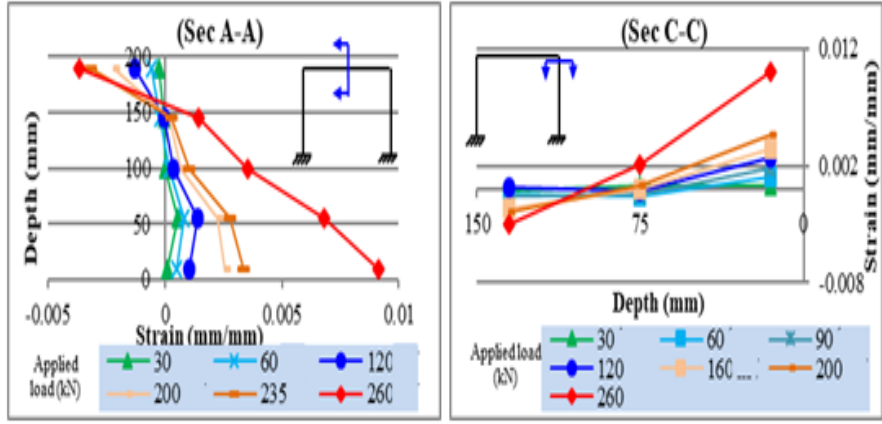

Fig. 21: Concrete strain distribution for frame (Fu-2P)

\section{Finite Element Analyses}

\subsection{Modelling the Frames}

A quarter of the full frame was used to model the frames utilizing symmetry of the frame, supports and loadings as shown in Figure (22). All frames were modeled and analyzed using finite element method by using a nonlinear finite element method package (ANSYS V. 12.1). A suitable boundary conditions were put at axes of symmetry. A convergence study on quarter model of the beam was carried out to determine an appropriate mesh density.

The convergence of results is obtained when an adequate number of elements are used in a model. This is practically achieved when an increase in the mesh has negligible effect on the results.

Figure (23) shows the relation between the number of elements and mid-span deflection for the control frame (F2-Co) was observed for the same applied load of $(170 \mathrm{kN})$. It can be noted from the figure below that the difference can be neglected when the number of elements increased from (36096) to (48260). So mesh about (36096) elements was adopted.
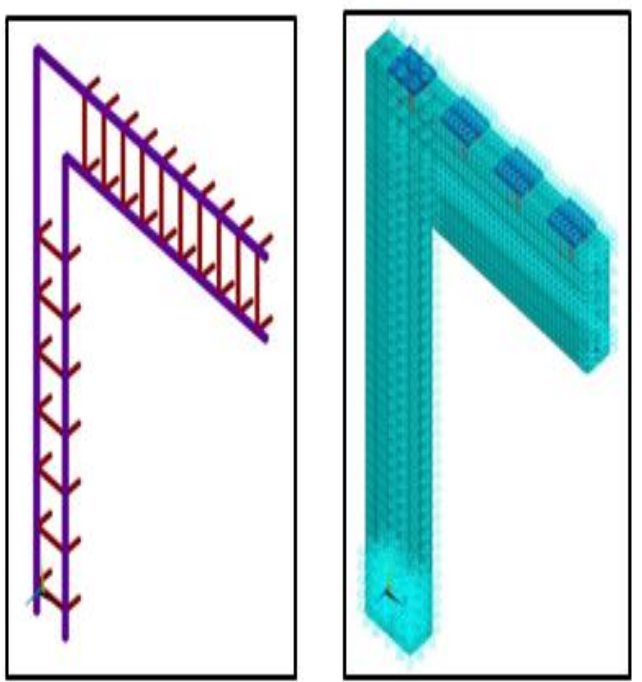

Fig. 22: Modelling for quarter frame 


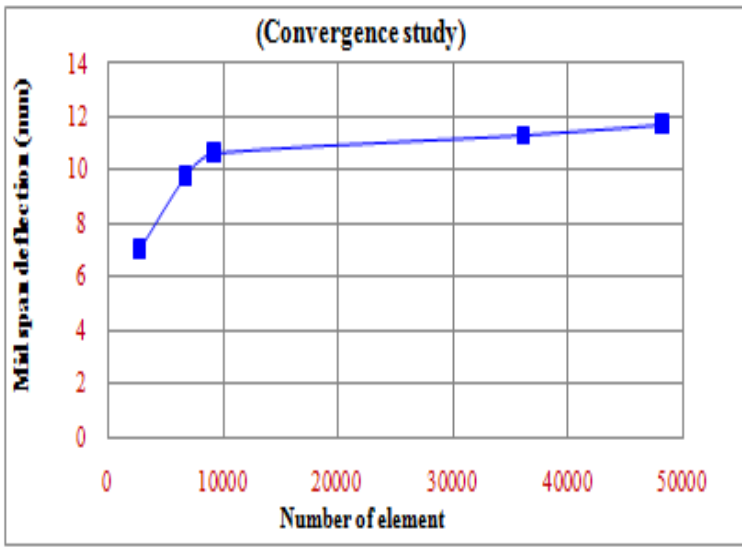

Fig. 23: Convergence study for finite element model

\subsection{Used Element}

The elements which were used in modelling frame were listed in Table (9) below and as shown in Figure(24) below.

\subsection{Material Properties}

Concrete properties which were used for solid concrete element 65 , are as listed in

\begin{tabular}{|c|c|}
\hline Element Type & Modeled material \\
\hline Solid 65 & Concrete material \\
\hline Spar1 link 8 & Flexural reinforcement \\
\hline Spar2 link 8 & Shear reinforcement \\
\hline Solid 45 & Steel plates \\
\hline Shell 41 & CFRP- sheet \\
\hline
\end{tabular}

Table (10) below.

Flexural and shear steel reinforcement material properties are listed in Error! Reference source not found.).

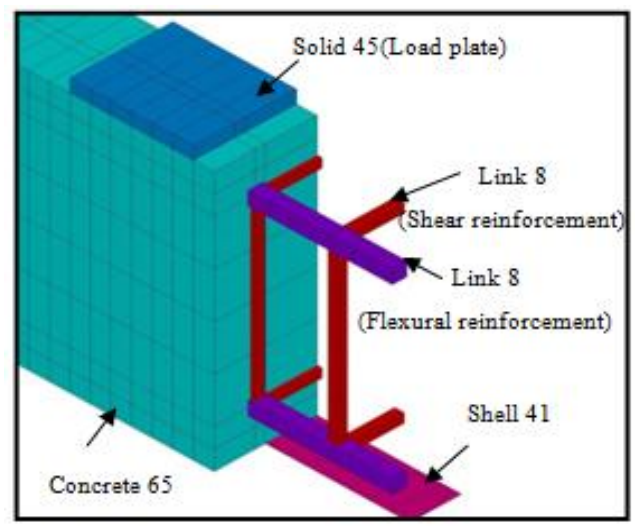

Fig. 24: Types of elements

Table (9): Element used in modeling frames

\begin{tabular}{|c|c|}
\hline \multicolumn{2}{|c|}{ Table (9): Element used in modeling frames } \\
\hline Element Type & Modeled material \\
\hline Solid 65 & Concrete material \\
\hline Spar1 link 8 & Flexural reinforcement \\
\hline Spar2 link 8 & Shear reinforcement \\
\hline Solid 45 & Steel plates \\
\hline Shell 41 & CFRP- sheet \\
\hline
\end{tabular}

Table (10): Concrete Properties

\begin{tabular}{|c|c|}
\hline Properties & Value \\
\hline Open Shear Transfer Coefficient & 0.2 \\
\hline Closed Shear Transfer Coefficient & 0.62 \\
\hline Uniaxial Cracking Stress & 7.37 \\
\hline Uniaxial Crushing Stress & 39.4 \\
\hline Modulus of elasticity (E) & 30600 \\
\hline Poisson's ratio (v) & 0.17 \\
\hline
\end{tabular}

Table (11): Flexural and shear steel reinforcement material properties

\begin{tabular}{|c|c|c|}
\hline Properties & Flexural rein forcement & $\begin{array}{c}\text { Shear } \\
\text { reinforcement }\end{array}$ \\
\hline As (mm2) & 111.97 & 48.64 \\
\hline $\begin{array}{c}\text { Modulus of elasticity (E) } \\
(\mathrm{MPa})\end{array}$ & 200000 & 200000 \\
\hline Poison's ratio (v) & 0.3 & 0.3 \\
\hline Fy (MPa) & 655 & 467 \\
\hline Tang mod & 20000 & 20000 \\
\hline
\end{tabular}

\subsection{Boundary Condition}

The applied load and boundary conditions for a quarter of the full frame were shown in Figure (25). The total applied load on it will be equal to $1 / 16$ from the total applied load and it distributed about area around the node.

\subsection{Two pours section modelled}

This section was modeled by using concrete material with weak properties (3 Mpa, $5 \mathrm{MPa}, 10 \mathrm{Mpa}, 12 \mathrm{Mpa}$ ), Weak concrete with $10 \mathrm{MPa}$ gives behavior similar to experimental results, as shown in Figure (26) below.

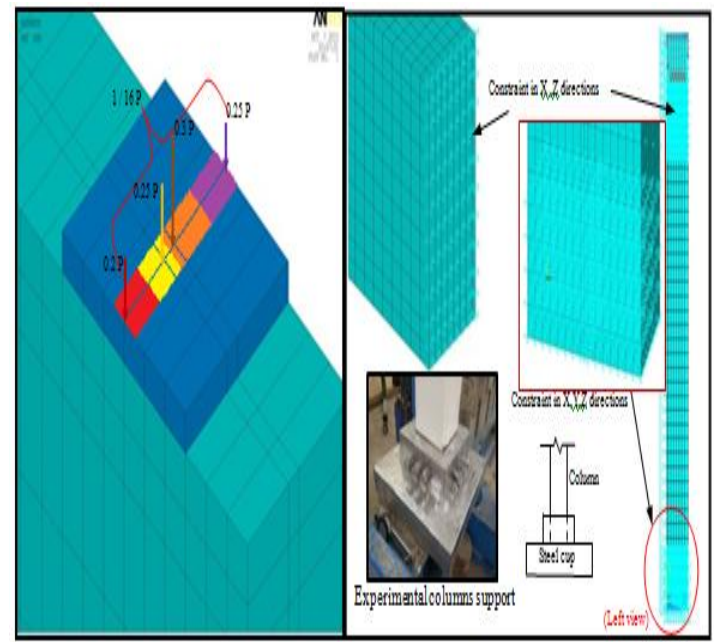

Fig. 25: Applied load and boundary conditions for a quarter frame

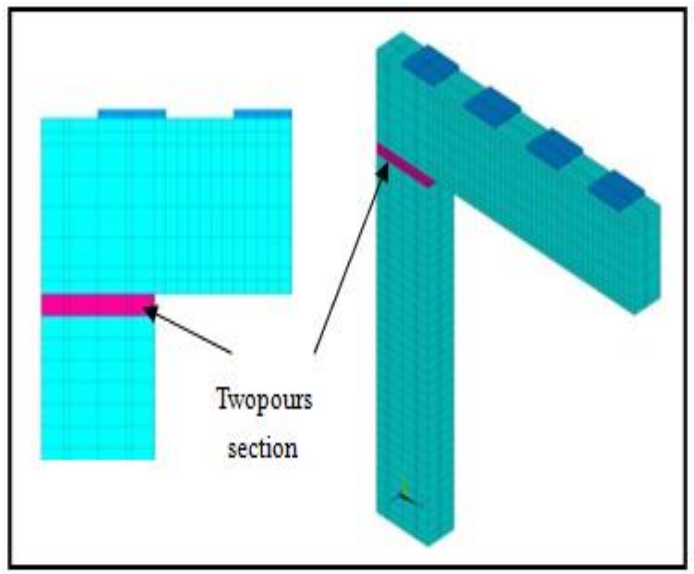

Fig. 26: Two pours section modelling

\subsection{Numerical Load - Deflection Curves for Tested Frames}

The numerical results give good agreement with experimental results, but the numerical results more than experimental that related to some assumptions, such as concrete isotropic behavior, full bond between concrete and steel, bilinear steel stress-strain diagram and full bond between CFRP and concrete. Numerical results were shown in Figure (27)to Figure (29). 


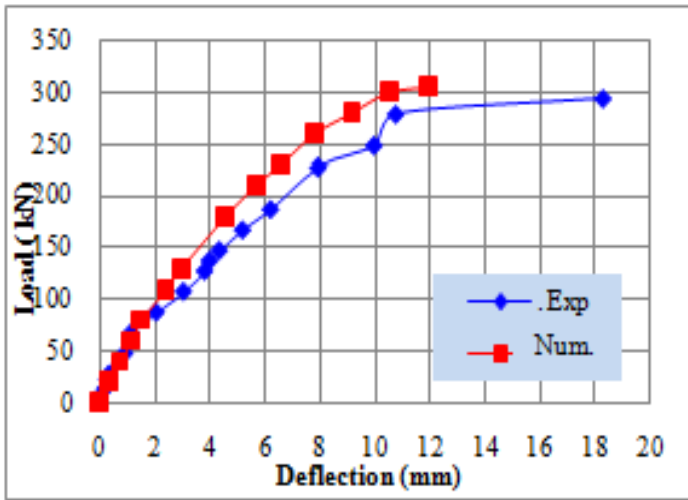

Fig. 27: Load deflection curve for frame (Fu-Co)

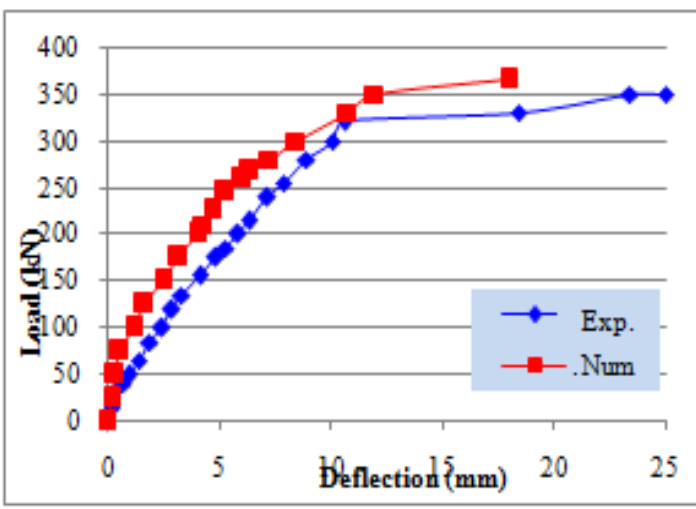

Fig. 28: Load deflection curve for frame (Fu-S)

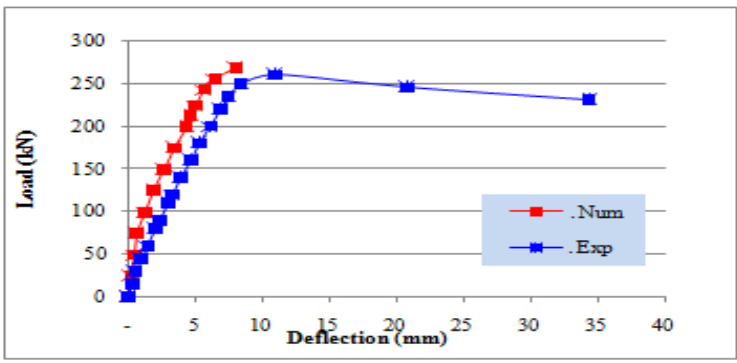

Fig. 29: Load deflection curve for frame (Fu-2P)

\section{Conclusions}

1. Using CFRP-sheet in a strengthening frame at beam and joints increase ultimate load for frame by $(19.45 \%)$.

2. Using CFRP-sheet in strengthening frame decrease equivalent deflection by $(-44.88 \%)$.

3. Casting frames in two pours (i.e. Cast column first separately from beam reduce ultimate load for frame by $(11.26 \%)$

4. Casting frames in two pours increasing deflection at mid span, because of the weak joint between beam and columns.

5. Maximum crack width in beam column joints for frame with two pours $(\mathrm{Fu}-2 \mathrm{P})$ is more than control frame by $(75 \%)$.

6. The finite element model used in the present study is able to simulate the strengthened reinforced concrete frames with CFRPsheet. The difference for mid span load -deflection relationship between experimental and numerical results was (4.28\%) only.

\section{References}

[1] ACI 440.2R-08. 2008. "Guide for the Design and Construction of Externally Bonded FRP Systems for Strengthening Concrete Structures." ACI Committee 440.2R-08 Report, American Concrete Institute.

[2] Al-Janabi, M. A. Q. and Alwash, N. A. 2003. "Optimal Design of Reinforced Concrete Space Structures Based on Nonlinear
Analysis.” M.Sc. Thesis, Civil Department, College of Engineering, University of Babylon, Iraq.

[3] Al-Mishhadani, S. A. and Al-Rubaie, M. F.2009. "A Data Base for Self-Compacting Concrete in Iraq."Eng. \& Tech. Journal Vol. 27 No. 6. Department of Building and Construction Engineering, University of Technology, Iraq, pp.1203-1220.

[4] Al-Nasrawi, J.T.A., Al-Sarraf, S. Z. and Alwash, N. A.,2008. "Ultimate Strength Capacity of R.C Space Frames Strengthened by FRP.” Ph.D. Thesis, Civil Department, College of Engineering, University of Babylon, Iraq.

[5] Al-Shimmari, I. K. 2006. "Nonlinear Finite Element Analysis of Reinforced Concrete Beam-Column Connection With Interface Element Under Cyclic Loading." M.Sc. Thesis, Civil Engineering Department, College of Engineering of the University of Babylon, Iraq.

[6] ASTM C39 M-05, "Standard Test Method for Compressive Strength of Cylindrical Concrete Specimens", Annual Book of ASTM Standards, American Society for Testing and Materials, pp.1-7.

[7] ASTM C496, "Standard Test Method for Splitting Tensile Strength for Cylindrical Concrete Specimens", American Society for Testing and Materials, 2004

[8] ASTM C78-02. 2002. "Standard Test Method for Flexural Strength of Concrete (Using Simple Beam with Third-Point Loading)." Annual Book of ASTM Standards, American Society for Testing and Materials.

[9] Behrouz Behnam, Pang Jen Lim and Hamid R. Ronagh. 2014. "Plastic hinge relocation in reinforced concrete frames as a method of improving post-earthquake fire resistance".Research Journal of the Insinuation of Structural Engineers (2): 21-31.doi 10.1016/j.istruc.2014.12.003

[10] British Standards, 1989"Method for Determination of Compressive Strength of Concrete Cubes."BS 1881: Part 116.

[11] CengizDundar and IlkerFatih Kara.2007."Three dimensional analysis of reinforced concrete frames with cracked beam and column elements." Department of Civil Engineering, Cukurova University, Turkey.

[12] European Federation Dedicated to Specialist Construction Chemicals and Concrete Systems (EFNARC). 2005."The European Guidelines for Self-Compacting Concrete Specification, Production and Use."

[13] Guerra, A. and Kiousis, P. D. 2006. "Design Optimization of Reinforced Concrete Structures" Colorado School of Mines, Division of Engineering, USA

[14] Iraq Specification No. 45 (1984),"Natural Sources for Gravel that is Used in Concrete and Construction." Baghdad.

[15] Iraq Specification No. 5 (1984), "Portland Cement", Baghdad.

[16] Marı'a E. Marante, Lorena Sua 'rez, Adriana Quero, Jorge Redondo, Betsy Vera, MaylettUzcategui, Sebastia 'n Delgado, Leandro R. Leo'n, Luis Nu 'ñez and Julio Flo 'rez-Lo 'pez. 2005. "Portal of damage: a web-based finite element program for the analysis of framed structures subjected to overloads." Advances in Engineering software (36): 346 -358

[17] MihaJukic', Boštjan Brank and Adnan Ibrahimbegovic. 2014. "Failure Analysis of Reinforced Concrete Frames by Beam Finite Element that Combines Damage, Plasticity and Embedded Discontinuity." Engineering Structures Journal (75): 507 -527.

[18] Shawkat, Waleed. 2008. "Hybrid Members Employing FRP Skin Reinforcement For Beam and Cladding Wall Applications." M.Sc. Thesis, Department of Civil Engineering, Queen's University, Kingston, Ontario, Canada.

[19] Sika, "Sikadur 330-Two Part Epoxy Impregnation Resin ", Technical Data Sheet, Edition 2, 2005.

[20] Sika, " Sika Warp®- 230C Woven carbon fiber fabric for structural strengthening", Technical Data Sheet, 2009.

[21] VikasGohel, Paresh V. Patel and Digesh Joshi. 2013. "Analysis of Frame using Applied Element Method (AEM)." Chemical, Civil and Mechanical Engineering Tracks of 3rd Nirma University International Conference on Engineering (NUiCONE 2012).

[22] Zou, X.K. and Chan, C. M. 2004. "Seismic Drift PerformanceBased Design Optimization of Reinforced Concrete Buildings. "World Conference on Earthquake Engineering, Vancouver, B.C., Canada. 